\title{
A Proliferation-Inducing Ligand Measurement
}

National Cancer Institute

\section{Source}

National Cancer Institute. A Proliferation-Inducing Ligand Measurement. NCI Thesaurus.

Code C111123.

The determination of the amount of a proliferation-inducing ligand present in a sample. 